\title{
Secretion of fibronectin by rat granulosa cells occurs primarily during early follicular development
}

\author{
J. A. Carnegie \\ Human IVF Laboratories, Reproductive Biology Unit, Department of Obstetrics and \\ Gynecology, The Loeb Institute for Medical Research, Ottawa Civic Hospital, Ottawa, Ontario, \\ Canada KIY $4 E 9$
}

\begin{abstract}
Summary. Rats were pretreated with oestradiol-17 $\beta$ or PMSG, treatments producing mainly preantral and antral follicles respectively. The granulosa cells from these two treatments, $\mathrm{E}_{2}$ - and PMSG-cells respectively, were cultured for 2 successive 24-h periods. Basal progesterone secretion, stimulated 3- to 5-fold by FSH, was almost 8fold higher by PMSG-cells than by $\mathrm{E}_{2}$-cells at 24 and $48 \mathrm{~h}$. Similarly, PMSG-cells secreted 16-fold more $20 \alpha$-dihydroprogesterone than did $\mathrm{E}_{2}$-cells, in the absence of FSH, and 6- to 10-fold more of the 20a-reduced metabolite in the presence of FSH. In contrast, fibronectin secretion by PMSG-cells was only about $60 \%$ and $30 \%$ that by $\mathrm{E}_{2}$-cells at 24 and $48 \mathrm{~h}$, respectively. Fibronectin secretion by $\mathrm{E}_{2}-$ and PMSG-cells was reduced in the presence of FSH at 24 and at $48 \mathrm{~h}$ of culture. While cells in all treatment groups underwent spreading during culture to become elongated and irregular in outline, elevated fibronectin secretion in vitro was accompanied by enhanced cellular spreading. At 24 and $48 \mathrm{~h}$ of culture respectively, the mean area occupied by $\mathrm{E}_{2}$-cells on the culture surface was $\times 2$ and $\times 1.6$ that by PMSG-cells. Coincident with its inhibitory effect on fibronectin secretion, FSH reduced the mean area occupied by $E_{2}$ - and PMSG-cells on the culture surface at both time intervals. These findings suggest that granulosa cell fibronectin secretion is a feature of early follicular development. It may be that the secretion of this adhesive glycoprotein by granulosa cells provides a pool of fibronectin which is used for basement membrane deposition during follicular growth.
\end{abstract}

Keyn'ords: fibronectin; granulosa cell; extracellular matrix; follicular development; rat

\section{Introduction}

Fibronectin is an extracellular matrix component which has been implicated in the regulation of cell shape, growth and differentiation as well as both cell-cell and cell-substratum adhesion (Ruoslahti et al., 1981; Yamada, 1981). Fibronectin is a dimer of two identical glycoprotein chains connected by disulphide bridges and can exist in two forms, plasma (soluble) fibronectin and cellular (insoluble) fibronectin, both of which have similar molecular properties and appear to be immunologically identical (Yamada \& Olden, 1978; Ruoslahti et al., 1981). A pivotal role for cellular fibronectin has been proposed, both in the organizaion of different extracellular matrix components and in the interactions of cell surfaces with each other and with the extracellular matrix, based on its complement of binding sites for a cell surface component as well as for collagen, hyaluronic acid, heparin and heparan sulphate (Hynes, 1981; Hynes \& Yamada, 1982).

Fibronectin has been shown to be secreted by rat (Skinner \& Dorrington, 1984) and bovine (Savion \& Gospodarowicz, 1980) granulosa cells during culture. Indeed, by Day 3, this adhesive glycoprotein can represent $20 \%$ of the total radiolabelled proteins secreted by granulosa cells isolated from preantral ovarian follicles (Skinner \& Dorrington, 1984). Fibronectin secretion appears 
to be inversely related to the in-vitro induction of steroidogenic activity within granulosa cells by gonadotrophin. Both follicle-stimulating hormone (FSH) and dibutyryl cyclic AMP, agents which stimulate granulosa cell production of progesterone and oestradiol-17 $\beta$, significantly reduce the secretion of fibronectin by rat granulosa cells during a 72-h culture period (Skinner et al., 1985). Gonadotrophin-releasing hormone, which has well known inhibitory influences on granulosa cell steroidogenesis (Hsueh \& Erickson, 1979; Gore-Langton et al., 1981), stimulates secretion of fibronectin by rat granulosa cell in vitro (Dorrington \& Skinner, 1986). However, the association between the differentiation of granulosa cells in vivo and their fibronectin secreting activity remains to be described.

In this study, this relationship was explored by culturing granulosa cells isolated from follicles at primarily either the preantral or antral stages of development and comparing their levels

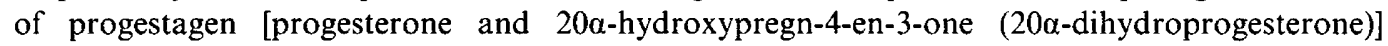
secretion with those of fibronectin, in the presence and absence of FSH. Also, the possible influence of endogenous fibronectin on cell spreading during culture was assessed by comparing various cell shape-related measures (area occupied on the culture surface, perimeter, and contour index) in relation to cytodifferentiation in vivo and in vitro.

\section{Materials and Methods}

Follicle treatments. Ovarian follicular growth was stimulated in immature Sprague-Dawley rats using the following two treatment schedules. Rats were either injected for 4 successive days with oestradiol (1 mg/rat/day, i.p., Days 26-29 \pm 1 ; Skinner \& Dorrington, 1984) and killed on the day after the final injection, or given a single dose of PMSG (4 i.u., i.p., morning of Day $28 \pm 1$; Fortune \& Armstrong, 1977) 2 days before tissue harvesting. Examination of ovarian serial sections showed that the two regimens synchronized follicular development to primarily the preantral ( $E_{2}$-cells) and antral (PMSG-cells) stages, respectively, when the animals were killed on Day $30 \pm 1$ (Carnegie \& Tsang, 1984). In addition, only the granulosa cells isolated from the more mature follicles of the PMSG-pretreated animals were found to be LH-responsive (Carnegie \& Tsang, 1984). The follicles resulting from each of the two animal pretreatment protocols were punctured in Eagle's minimal essential medium (MEM; Gibco Laboratories, Mississauga, Ontario, Canada) to release the granulosa cells which were collected by centrifugation ( $180 \mathrm{~g}, 10 \mathrm{~min})$. Non-viable cells were removed using a sequential trypsin-DNase treatment (Farookhi, 1982) which increased the percentage of viable cells within the population from an initial value of $20-30 \%$ to a final level of $90-95 \%$. Briefly, the cell suspension ( $10^{6}$ cells $/ \mathrm{ml}$ ) was incubated at $37^{\circ} \mathrm{C}$ with trypsin $(50 \mu \mathrm{g} / \mathrm{ml}$; Sigma Chemical Co., St Louis, MO, USA) for 1 min and subsequently with excess soy bean trypsin inhibitor (Sigma) and finally for $5 \mathrm{~min}$ with DNase I $\left(25 \mu \mathrm{g} / \mathrm{ml}\right.$; Sigma). The $\mathrm{E}_{2}-$ and PMSGcells were each washed twice with MEM, divided into two groups, and approximately $3 \times 10^{5}$ viable cells per well were cultured (at $37^{\circ} \mathrm{C}$ under an atmosphere of $5 \% \mathrm{CO}_{2}$ and $95 \%$ air) in $1 \mathrm{ml} \mathrm{MEM}$ and in the presence or absence of $150 \mathrm{ng}$ NIAMDD oFSH-14/ml. Culture was for $48 \mathrm{~h}$ with medium collection and replacement at $24 \mathrm{~h}$. Falcon $24-$ well plates were used and round glass coverslips were included in each well when the cells were to be examined by microscopy after 24 or $48 \mathrm{~h}$ of culture.

Progestagen radioimmunoassays and fibronectin ELISA. The medium was collected after the first and second 24-h culture periods and divided so that one-half could be extracted with ether for the subsequent determination of secreted progesterone and $20 \alpha$-dihydroprogesterone concentrations by radioimmunoassay (Orczyk et al., 1979) while the remainder was immediately frozen for the later measurement of fibronectin amounts by a competitive enzymelinked immunosorbent assay (ELISA). The antiserum to progesterone has been previously characterized (Leung \& Armstrong, 1979). The antiserum against $20 \alpha$-dihydroprogesterone cross-reacts $8.7 \%$ with $20 \beta$-hydroxypregn-4-en-3one and $<0.1 \%$ with oestrogens, androgens and other progestagens (Morley et al., 1987). The intra- and interassay coefficients of variation for both the progesterone and $20 \alpha$-dihydroprogesterone assays were $<10$ and $20 \%$, respectively.

The ELISA for fibronectin was a modification of that described by Skinner et al. (1985) and, with the exception of the initial preincubation and plate coating procedures, was carried out at room temperature. Rat fibronectin (Terochem Laboratories Ltd, Toronto, Ontario, Canada) was used both to coat the Immulon 2 microtitre plates (Dynatech Labs, Alexandria, VA, USA) and to prepare the standards. Each microtitre plate well was incubated (overnight at $4^{\circ} \mathrm{C}$ ) with $100 \mu \mathrm{l} 20 \mathrm{~mm}-\mathrm{Na}_{2} \mathrm{CO}_{3}$ buffer, $\mathrm{pH} 9 \cdot 6$, containing $200 \mathrm{ng}$ rat fibronectin. In addition, fibronectin standards $\left[0-320 \mathrm{ng}\right.$ in $100 \mu \mathrm{l} 0.5 \%$ (v/v) Tween-20 in $10 \mathrm{mM}-\mathrm{NaH}_{2} \mathrm{PO}_{4}$ containing $0.85 \%(\mathrm{w} / \mathrm{v}) \mathrm{NaCl}, \mathrm{pH} 7.4$ (Tween-PBS)] and samples were preincubated (overnight at $4^{\circ} \mathrm{C}$ ) in plastic tubes with $100 \mu 1$ Tween-PBS containing goat anti-human fibronectin (Terochem) such that the final dilution of the antiserum was $1 / 20000$. After removal of the fibronectin coating solution and washing of the microtitre plates with PBS followed by Tween-PBS, the preincubated antigen-antibody solutions were added $(200 \mu \mathrm{l}$ per well) and the incubation continued for a further $30 \mathrm{~min}$. The wells were then emptied, rinsed several times with Tween-PBS and further incubated (45 min) with peroxidase- 
conjugated pig anti-goat IgG (Intermedico, Willowdale, Ontario, Canada). Again, the plates were washed thoroughly with Tween-PBS followed by sodium citrate buffer (19 mM-sodium citrate, $4 \mathrm{~mm}$-dibasic sodium phosphate, pH $4 \cdot 25$ ) and; finally, to each well was added $100 \mu \mathrm{l} 0.36 \mathrm{~mm}$-2,2'-azino-di-[3-ethylbenzthiazoline sulphonate (6)] (ABTS; Boehringer Mannheim, Dorval, Quebec, Canada) in the same sodium citrate buffer. Colour development was permitted for $30 \mathrm{~min}$, and then the absorbance of each well was read using a Dynatech microplate reader and $405 / 490 \mathrm{~nm}$ filters. This ELISA is linear from 1.25 to $40 \mathrm{ng}$ and has a sensitivity of $1-2 \mathrm{ng}$.

Morphometric analysis of cell shape changes. In 2 of the 4 experiments, cells attached to coverslips ( 2 per treatment group in each experiment) were prepared for the evaluation of cell spreading during culture by fixation (overnight at $4^{\circ} \mathrm{C}$ ) with $2 \%$ glutaraldehyde and then routine staining with haematoxylin and eosin. Random areas of reasonably isolated cells (individual cell boundaries could be distinguished) were photographed on $35 \mathrm{~mm}$ Plus X film which was projected onto a digitizer pad (Summagraphics Corporation, Fairfield, CT, USA) at a final magnification of $\times 1320-$ 3300. Individual cell outlines were traced with a cursor and alterations in cell area and shape were quantified using the method of Dardick et al. (1984) which has been previously employed to study granulosa cell morphology in this laboratory (Carnegie et al., 1987). This involved the determination of three values for each cell: perimeter, the surface area occupied on the coverslip, and contour index [a size-independent measurement of the shape of a profile indicating cell shape deviation from a perfect circle, which has a contour index of 3.54 (Schrek, 1972)] using an MSA II computer (Atlantic Scientific Systems Group, Ottawa, Ontario, Canada).

Immunolocalization of fibronectin. In 2 of the 4 experiments, cells attached to coverslips ( 2 per treatment group in each experiment) were subjected to one of two fixation/permeabilization protocols to render intracellular fibronectin and possibly that located between the basal cell surface and the coverslip accessible to the primary and secondary antibodies (Turksen et al., 1984). The milder extraction treatment involved fixation of the cells (10 min at room temperature) with $3.7 \%$ paraformaldehyde in phosphate-buffered saline (PBS, $\mathrm{pH} 7.0$ ), followed by rinsing with PBS and then permeabilization with $0.1 \%$ (in PBS) Nonidet P-40 (Sigma) for $20 \mathrm{~min}$ at room temperature. With the second protocol, the plasma membranes and cellular cytoplasm were more extensively digested ( 5 min at room temperature) with $0.5 \%$ Trion X-100 (Sigma); the residual membrane fragments and the secreted matrix were then rinsed several times with PBS and fixed with $3.7 \%$ paraformaldehyde for $10 \mathrm{~min}$ at room temperature. The extent of cellular digestion after each of the two treatments was monitored by phase-contrast microscopy. In both cases, the coverslips were rinsed further with PBS and then incubated ( $45 \mathrm{~min}$ at room temperature), initially with a specific antiserum to human fibronectin raised in the goat (Terochem), and then with fluorescein isothiocyanate-labelled pig anti-goat IgG (Intermedico). For control coverslips, incubation with the first antibody was omitted. The coverslips were then mounted in $0.1 \%$ p-phenylenediamine in $50 \%$ glycerol (to retard bleaching of fluorescence during ulraviolet illumination; Johnson \& Nogueira-Araujo, 1981) and observed with a Carl Zeiss microscope equipped with epifluorescence optics.

Statistical analysis. All data were treated statistically by analysis of variance. Due to heterogeneity of variance, as indicated by Bartlett's test of homogeneity of variances, all data were converted to natural logarithms before statistical evaluation.

\section{Results}

\section{Secretion of progestagens and fibronectin}

Throughout the culture period, the basal secretion of progesterone and of $20 \alpha$-dihydroprogesterone by PMSG-cells was almost 8 -fold $(P<0.01)$ and about 16 -fold $(P<0.01)$, respectively, that by $E_{2}$-cells (Fig. 1). In response to $\mathrm{FSH}(150 \mathrm{ng} / \mathrm{ml})$, the secretion of progesterone was stimulated to a greater extent in $\mathrm{E}_{2}$-cells $(4.5$-fold, $P<0.01)$ than in PMSG-cells (3-fold, $\left.P<0.01\right)$ at both time intervals (Fig. 1). However, the amount of progesterone released into the medium by the more mature FSH-stimulated PMSG-cells was still 5.8-fold $(P<0.01)$ and 4.4 -fold $(P<0.01)$ greater than that secreted by FSH-stimulated $\mathrm{E}_{2}$-cells at 24 and $48 \mathrm{~h}$ of culture, respectively. Similarly, while $\mathrm{E}_{2}$-cell secretion of $20 \alpha$-dihydroprogesterone was more responsive $(P<0.01)$ to FSH than that by PMSG-cells at both $24 \mathrm{~h}(3 \cdot 3$-fold $v s 2 \cdot 2$-fold) and $48 \mathrm{~h}$ (8.7-fold $v s 3 \cdot 1$-fold $)$ of culture, the FSH-stimulated PMSG-cells secreted 6- to 10-fold more of the 20 $\alpha$-reduced metabolite than did the $\mathrm{E}_{2}$-cells cultured with gonadotrophin.

In contrast, PMSG-cells secreted less fibronectin than did $\mathrm{E}_{2}$-cells. This was especially apparent during the second 24-h culture period, when $\mathrm{E}_{2}$-cell fibronectin secretion increased by 4-fold while that by PMSG-cells was elevated by only $85 \%(P<0.01)$. $\mathrm{E}_{2}$-cell fibronectin secretion was $\times 1.6$ and $\times 3.5$ that by PMSG-cells at 24 and $48 \mathrm{~h}$, respectively (Fig. 2). Unlike its effect on progesterone secretion, FSH significantly $(P<0.01)$ reduced fibronectin secretion by $\mathrm{E}_{2}$ - and PMSG-cells at the 

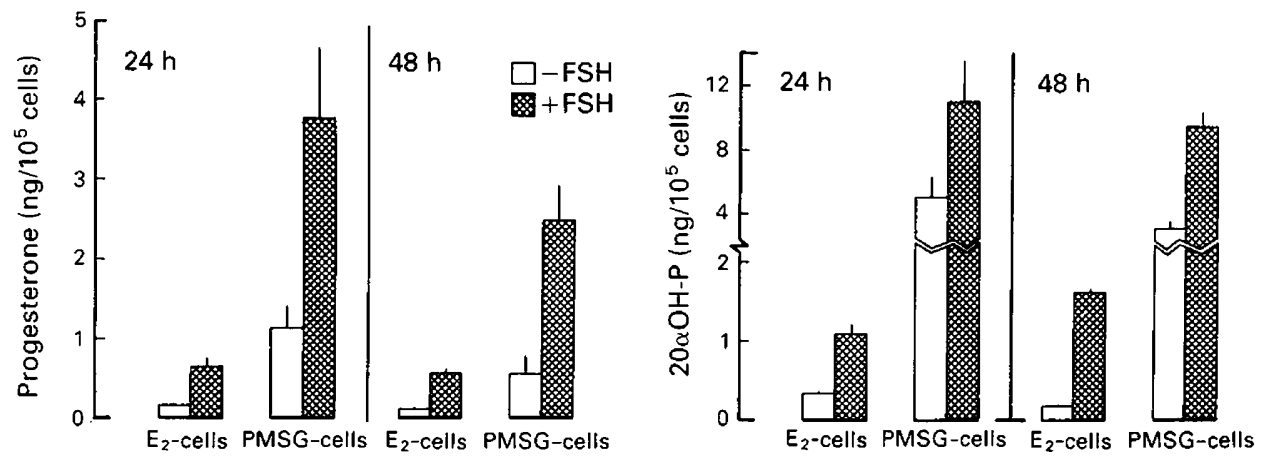

Fig. 1. Basal and FSH-stimulated secretion of progesterone and $20 \alpha$-dihydroprogesterone ( $20 \alpha-\mathrm{OH}-\mathrm{P})$ by $\mathrm{E}_{2}$ - and PMSG-cells from rat follicles during 2 successive 24 -h periods of culture. Each bar represents the mean \pm s.e.m. of 12-16 cultures from 3-4 experiments.

two time intervals (Fig. 2). At $24 \mathrm{~h}$ of culture, medium levels of fibronectin were reduced by only about $30 \%$, but, during the second 24 -h culture period, fibronectin secretion by $\mathrm{E}_{2}$ - and PMSGcells cultured in the presence of FSH was only $25 \%$ and $40 \%$, respectively, of that by these cells cultured in the absence of gonadotrophin (Fig. 2).
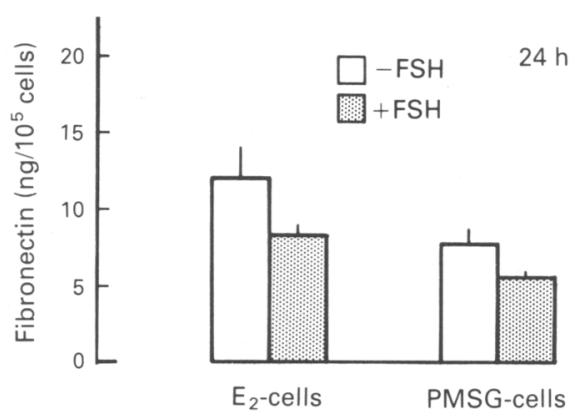

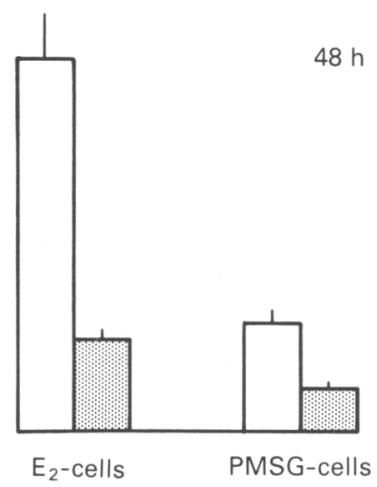

$48 \mathrm{~h}$

Fig. 2. Fibronectin secretion by $E_{2}$ - and $P M S G$-cells from rat follicles cultured for 2 successive 24-h periods in the presence or absence of FSH. Each bar is the mean \pm s.e.m. of $15-16$ cultures from 4 experiments.

\section{Quantification of cell spreading}

Elevated fibronectin secretion was accompanied by enhanced cell spreading during culture. Cells in all treatment groups underwent various degrees of spreading with the formation of cytoplasmic extensions during culture. However, at $24 \mathrm{~h}$ (Fig. 3), the mean area occupied by $\mathrm{E}_{2}$-cells on the culture surface was twice $(P<0 \cdot 01)$ that occupied by PMSG-cells. The $\mathrm{E}_{2}-$ and PMSG-cells continued to spread during the second $24 \mathrm{~h}$ culture period with the mean area occupied by $\mathrm{E}_{2}$-cells exceeding that occupied by PMSG-cells by almost $60 \%(P<0.01$; Fig. 3). Coincident with its inhibitory effect on fibronectin secretion, FSH reduced the mean area occupied by $E_{2}$ - and PMSGcells on the culture surface by $35 \%$ at $24 \mathrm{~h}$ and by 51 and $67 \%$, respectively, at $48 \mathrm{~h}$ of culture $(P<0.01$; Fig. 3).

Cultured granulosa cells were a heterogeneous population; for example, an examination of the distribution of the areas of $\mathrm{E}_{2}$-cells cultured for $24 \mathrm{~h}$ in the absence of gonadotrophin revealed that the mean cell area of $444 \pm 15 \mu \mathrm{m}^{2}$ (Fig. 3) actually represented a broad range of areas with $74 \%$ of 


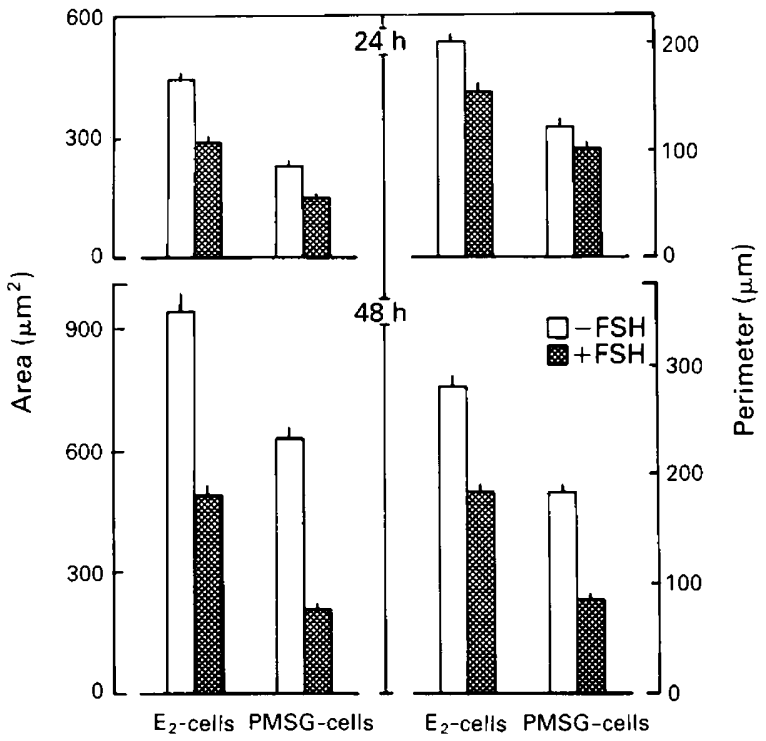

Fig. 3. Mean areas and perimeters of $E_{2}-$ and PMSG-cells from rat follicles following culture for 24 or $48 \mathrm{~h}$ in the presence or absence of FSH. Each bar represents the mean \pm s.e.m. of $120-176$ cells.

the cells distributed almost equally between 225 and $600 \mu \mathrm{m}^{2}$ (Fig. 4a). PMSG-cells (visualized after $24 \mathrm{~h}$ of culture) were also distributed within this range, but the distribution was shifted to the left, such that $84 \%$ of the cells had areas of $375 \mu \mathrm{m}^{2}$ or less (compared with $42 \%$ for $\mathrm{E}_{2}$-cells; Fig. 4a). Culture in the presence of FSH caused the distribution to shift even further to the left; $75 \%$ and $96 \%$ of $\mathrm{E}_{2^{-}}$and PMSG-cells, respectively, had areas of $375 \mu \mathrm{m}^{2}$ or less (Fig. 4a). Cells in all treatment groups continued to spread during the second 24-h culture period, but again, to varied extents such that $95 \%$ of $\mathrm{E}_{2}$-cells were distributed between 180 and $1800 \mu \mathrm{m}^{2}$ with a peak $(28 \%)$ in the interval $540-720 \mu \mathrm{m}^{2}$ (Fig. 4b). Treatment in vivo or in vitro with gonadotrophins caused this distribution to shift to the left. Whereas $43 \%$ of $E_{2}$-cells had areas of $\leqslant 720 \mu \mathrm{m}^{2}, 66 \%$ of PMSGcells and 85 and $98 \%$ of FSH-treated $\mathrm{E}_{2}$ - and PMSG-cells, respectively, had areas falling within this range.

Similarly, the mean perimeters of PMSG-cells decreased $(P<0.01)$ to $60 \%$ and $65 \%$, respectively, of those of $E_{2}$-cells at 24 and $48 \mathrm{~h}$ of culture and these values were further reduced in the presence of FSH by about $20 \%$ at $24 \mathrm{~h}$ and by $35-55 \%$ at $48 \mathrm{~h}$ (Fig. 3). Mean cell contour index was largely unaffected by either degree of cell differentiation in vivo at the time of isolation or cell treatment in vitro (Table 1). With the exception of PMSG-cells which had been cultured for $48 \mathrm{~h}$ in the presence of $\mathrm{FSH}$, mean contour indices for all other treatment groups were in excess of $7 \cdot 0$, reflecting the highly irregular outlines of these cells (Table 1). After $48 \mathrm{~h}$ of culture with FSH, a number of PMSG-cells appeared rounded and quite regular in outline and this is indicated by a shift in the mean contour index from $7.4 \pm 0.2$ (no FSH) to $5.9 \pm 0.2$ ( + FSH, $P<0.01$ ).

\section{Immunolocalization of fibronectin}

There was fairly uniform cytoplasmic staining for fibronectin seen in granulosa cells after $48 \mathrm{~h}$ of culture, regardless of treatment in vivo or in vitro (Figs 5a-d). Treatment with detergent preceding fixation with paraformaldehyde allowed fibronectin associated with the basal cell surface to be visualized (Figs 5e-g). Phase-contrast microscopy of these cells indicated that most, and in some cases all (Fig. 5e), of the cellular cytoplasmic contents and plasma membranes had been removed by this extraction procedure. While the overall staining intensity was reduced, when compared with 

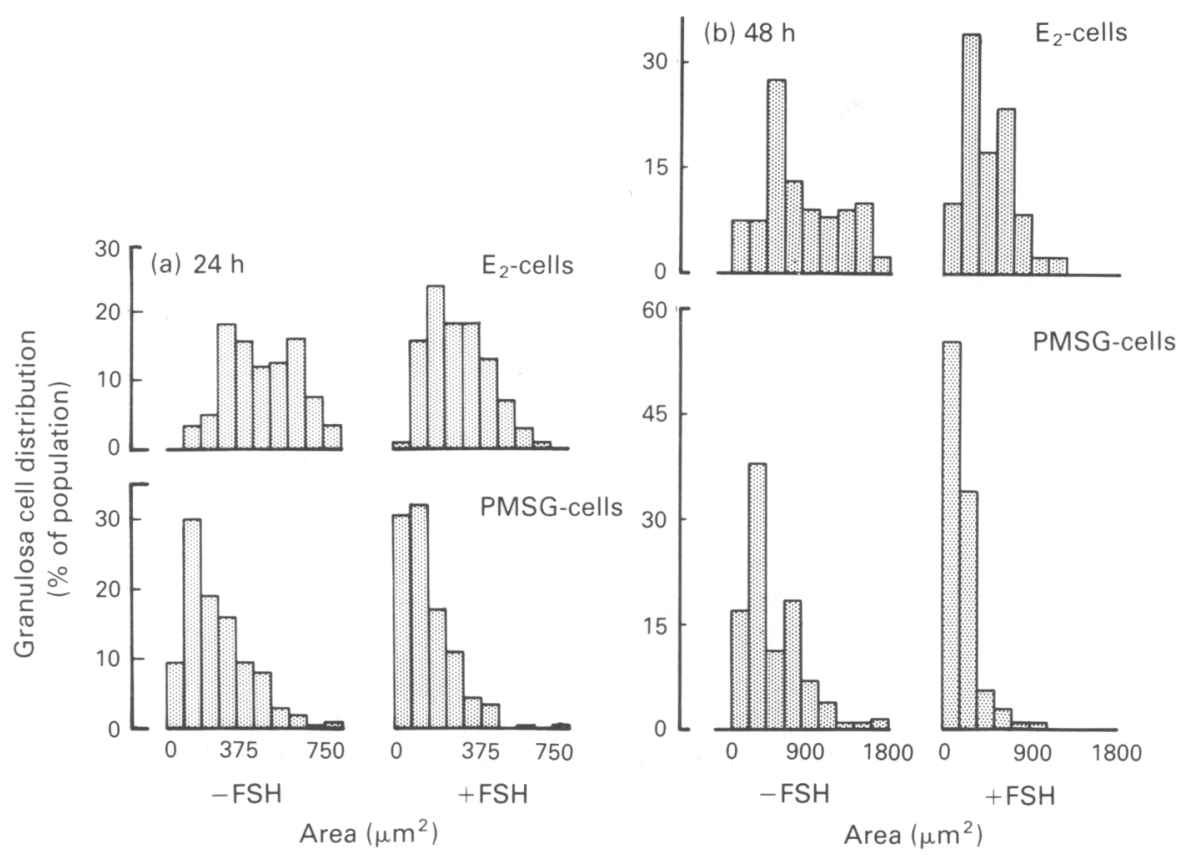

Fig. 4. Cell distribution based on area occupied on the culture surface of $E_{2}-$ and PMSG-cells from rat follicles cultured for $24 \mathrm{~h}$ (a) or $48 \mathrm{~h} \mathrm{(b)} \mathrm{in} \mathrm{the} \mathrm{presence} \mathrm{or} \mathrm{absence} \mathrm{of} \mathrm{FSH.} \mathrm{In} \mathrm{(a),} \mathrm{areas}$ from 0 to $750 \mu \mathrm{m}^{2}$ are indicated, with each bar representing $75 \mu \mathrm{m}^{2}$. In (b), the range of areas is $0-1800 \mu \mathrm{m}^{2}$ and each bar represents $180 \mu \mathrm{m}^{2}$. Data were derived from measurements of 120-176 cells per treatment group.

Table 1. Mean contour indices of $E_{2}$ - and PMSGcells from rat follicles after 24 and $48 \mathrm{~h}$ of culture in the presence of FSH

\begin{tabular}{llll}
\hline & & \multicolumn{2}{c}{ Contour Index } \\
\cline { 3 - 4 } & Cell type & No FSH & + FSH \\
\hline \multirow{2}{*}{$24 \mathrm{~h}$} & E $_{2}$-cells & $9 \cdot 7 \pm 0 \cdot 3$ & $9 \cdot 0 \pm 0 \cdot 3$ \\
& PMSG-cells & $7 \cdot 9 \pm 0 \cdot 3$ & $7 \cdot 7 \pm 0 \cdot 3$ \\
$48 \mathrm{~h}$ & E $_{2}$-cells & $9 \cdot 1 \pm 0 \cdot 2$ & $8 \cdot 5 \pm 0 \cdot 2$ \\
& PMSG-cells & $7 \cdot 4 \pm 0 \cdot 2$ & $5 \cdot 9 \pm 0 \cdot 2$ \\
\hline
\end{tabular}

Values are the mean \pm s.e.m. $(n=120-176$ cells $)$.

Figs 5(a)-(d), fibronectin associated with the limiting cell membrane could often be seen as a sharp outline to the cell (Figs 5f, g) and, when cell extraction was more extensive, the fibrillar pattern of fibronectin deposition between the cellular basal and culture surfaces was apparent (Fig. 5e). The bright nuclear fluorescence appeared yellow when visualized and its presence in cells which had undergone Triton X-100 permeabilization followed by fixation in paraformaldehyde only (no exposure to antibodies) indicated that it was non-specific fluorescence resulting from cell preparation for immunostaining. The cell shown in Fig. 5(h) was incubated with only the second antibody, the FITC-labelled pig anti-goat IgG. 

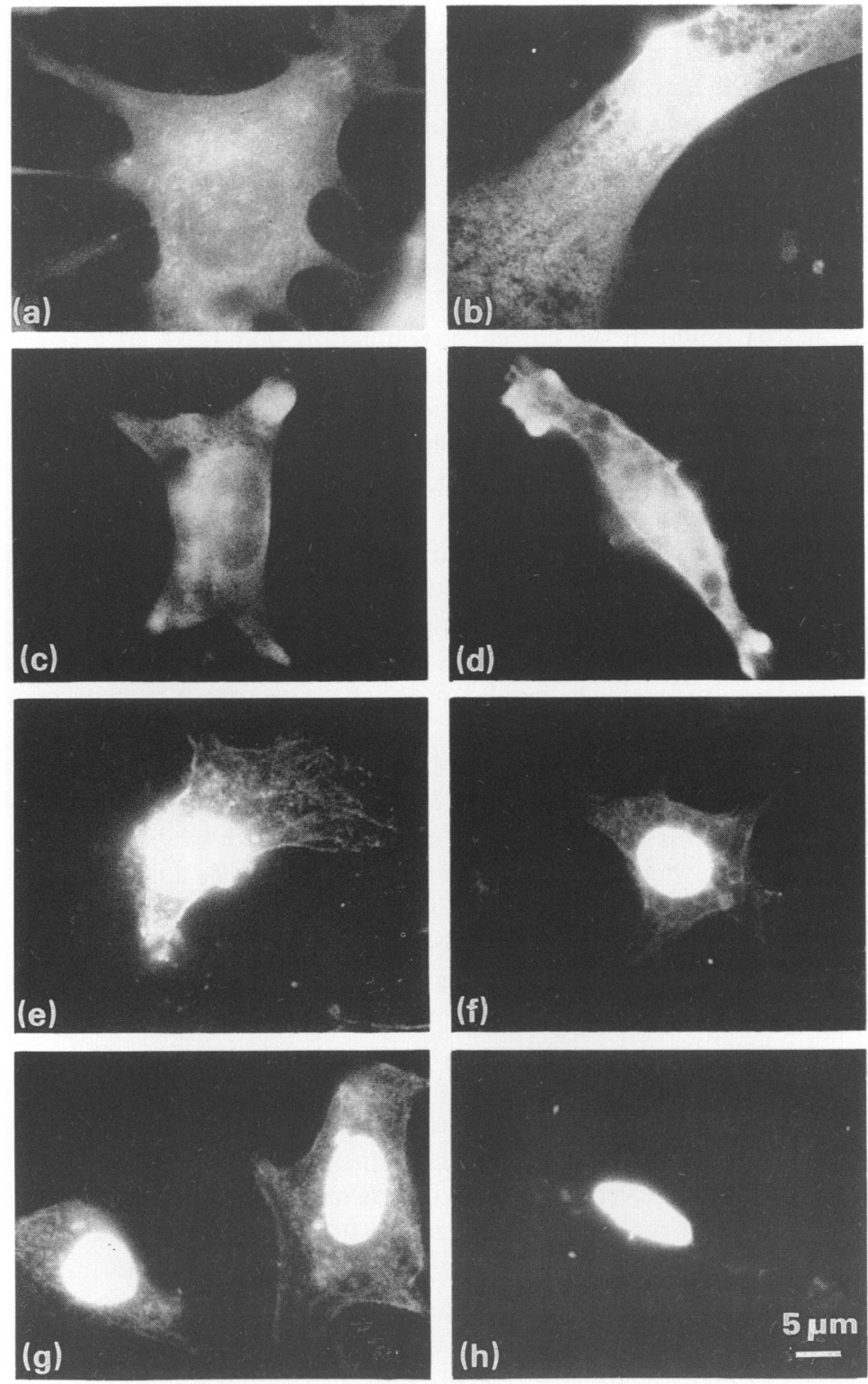

Fig. 5. Rat granulosa cells incubated with goat anti-human tibronectin and then fluorescein isothiocyanate-labelled pig anti-goat IgG after fixation in 3.7\% paraformaldehyde followed by permeabilization with $0 \cdot 1 \%$ Nonidet P-40 (a-d) or extraction with $0.5 \%$ Triton X-100 followed by fixation in $3.7 \%$ paraformaldehyde $(\mathbf{e}-\mathbf{h})$, to permit the localization of primarily intracellular fibronectin or that associated with the basal cell surface, respectively. Shown above are $\mathrm{E}_{2}$ cells cultured $(48 \mathrm{~h})$ either with $(\mathrm{b}, \mathrm{g})$ or without $(\mathrm{a}, \mathrm{e}) \mathrm{FSH}$ as well as PMSG-cells cultured $(48 \mathrm{~h})$ in the presence $(\mathrm{d})$ or absence $(\mathrm{c}, \mathrm{f})$ of the gonadotrophin. The bright nuclear fluorescence seen in $\mathrm{e}-\mathrm{h}$ is an artefact resulting from the Triton extraction.

\section{Discussion}

In this study, two different animal pretreatment protocols for the stimulation of follicular develop-

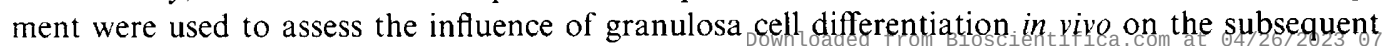


ability of these cells to secrete fibronectin in vitro. Granulosa cells isolated from less mature follicles, not yet very active in progestagen biosynthesis, secreted considerably more fibronectin during a 48-h culture period than did the more steroidogenically competent cells isolated from the preovulatory follicles of PMSG-primed rats. These findings suggest that the production of this adhesive glycoprotein is a feature of early follicular development and that, as follicular differentiation proceeds towards ovulation, the emphasis switches from the production of fibronectin to that of steroid hormones. This suggestion is supported by the in-vitro studies of Skinner \& Dorrington (1984) demonstrating that the stimulation of aromatase activity by FSH within rat granulosa cells isolated from preantral follicles was accompanied by decreased release of fibronectin into the culture medium. Indeed, it was found in the current investigation that $\mathrm{FSH}$, at a concentration which stimulated progestagen biosynthesis by granulosa cells isolated at each of the two stages of cytodifferentiation, concomitantly inhibited the secretion of this glycoprotein. Furthermore, Dorrington \& Skinner (1986) have reported that GnRH, which antagonized FSH-induced steroid hormone biosynthesis by rat granulosa cells, increased fibronectin secretion by these cells during a 72-h culture period. In addition, insulin, a hormone which has been shown to enhance FSH- and hCGstimulated steroidogenesis by pig granulosa cells (May \& Schomberg, 1981), dose-dependently reduced the secretion of fibronectin by rat granulosa cells in vitro (Skinner et al., 1985). Finally, studies of granulosa cell ultrastructure have revealed that, early in follicular development, the cytoplasm is relatively devoid of lipid but is filled with an abundant array of granular endoplasmic reticulum with dilated cisternae, evidence in favour of an active role in protein biosynthesis (Motta \& Van Blerkom, 1979).

In addition to being secreted into the extracellular fluid as a soluble product, fibronectin can also be deposited on cell surfaces and within extracellular matrices (Yamada \& Olden, 1978; Ruoslahti et al., 1981). The question must therefore be asked as to whether the reduction in fibronectin secretion by the more steroidogenically active granulosa cells actually represents decreased production or increased deposition of this glycoprotein. Skinner \& Dorrington (1984) analysed total cellular radiolabelled proteins by gel electrophoresis and found that fibronectin was a minor component whose concentration actually decreased slightly following culture of granulosa cells with FSH and concluded that the inhibition by this gonadotrophin did reflect a decrease in synthesis rather than enhanced deposition. While cell-associated fibronectin was not quantitatively assessed in this investigation, results of the immunolocalization studies looking at cytoplasmic fibronectin and that deposited on the culture surface beneath the cells did show uniform staining among the various in-vivo and in-vitro treatment groups.

The role of granulosa cell-derived fibronectin during early follicular development remains to be clearly defined. The results of the immunolocalization studies reported here indicated that a proportion of the fibronectin remained associated with the granulosa cells during culture. However, there was also a considerable amount of this glycoprotein released into the medium as a soluble product. Fibronectin has been shown to be a component of bovine follicular fluid (Savion \& Gospodarowicz, 1980). Indeed, granulosa cells were proposed to be a source of this fibronectin due to the existence of a blood-follicle barrier to substances having molecular weights greater than $1.5 \times 10^{5}$ (Shalgi et al., 1973) thereby preventing the diffusion of plasma-derived fibronectin $\left(M_{\mathrm{r}} 2.2 \times 10^{5}\right)$ into this fluid compartment. However, it has also been suggested that the secretion of soluble fibronectin in vitro may represent, at least to some extent, disrupted organization of the secreted fibronectin into extracellular matrix fibrils due to a reduction in collagen synthesis in the absence of sufficient ascorbic acid (Hynes, 1981).

Fibronectin, with its binding domains for collagen, hyaluronic acid, heparin, heparan sulphate and cell surfaces, is an important component of basement membranes in a number of different tissues (Hynes, 1981; Hynes \& Yamada, 1982). The presence of fibronectin in the follicular basement membrane separating the granulosa and theca cell compartments has been shown by immunofluorescence techniques (Bagavandoss et al., 1983). Indeed, the dramatic increase in follicle diameter during preparation for ovulation necessitates considerable synthesis and secretion $28 f_{2}$ va rious 
extracellular matrix components (including fibronectin) in order to maintain these basement membranes which not only support the outer layer of granulosa cells but also provide a semi-permeable barrier between the avascular granulosa cell and the vascularized theca cell compartments. It may be that the fibronectin component, at least, is largely provided by granulosa cells at the early stages of follicular development.

The possible influence of various constituents of the follicular basement membrane on granulosa cell form and function has been investigated using a number of in-vitro approaches and point to the importance of considering the interactions that each of these components may have with the cell surface. Morley et al. (1987) observed that granulosa cells maintained on a fibronectin-coated substrate appeared more spread than those grown on plastic. In this study, changes in the area and shape of cells secreting different amounts of fibronectin in vitro were measured and it was found that, while cells in all treatment groups did undergo spreading during the 24- and 48-h culture periods, there was a positive association between the secretion of this adhesive glycoprotein and the ability of these cells to spread during culture. On the other hand, the culture of bovine granulosa cells on extracellular matrix was associated with the formation of three-dimensional aggregates composed of cells with fairly high profiles (Furman et al., 1986). Rat granulosa cells cultured within collagen gels remain quite rounded, rather than undergoing the marked speading characteristic of culture on plastic (Carnegie et al., 1988). With regard to the extracellular matrix and granulosa cell function in vitro, $\mathrm{LH}$ receptors within antral follicles of the rat are preferentially associated with the layers of granulosa cells in closest association with the limiting basement membrane (Amsterdam et al., 1975; Bortolussi et al., 1977) and the peripheral granulosa cells are also those which are more steroidogenically active, assessed in terms of the localization of $3 \beta$-hydroxysteroid dehydrogenase (Prabhu \& Weisz, 1970) and cytochrome P-450 (Zoller \& Weisz, 1978).

The influences of the various extracellular matrix components on cell shape may relate to interactions between these extracellular proteins and the cytoskeleton. Because of the more rounded shape of bovine granulosa cells maintained on extracellular matrix, Furman et al. (1986) suggested that the extracellular matrix components may induce clustering of proteoglycans in the cell membranes and that this may in turn cause some reorganization of the cytoskeleton. Orly \& Sato (1979) found that the permissive effect of fibronectin on cell division was not mimicked by the more generalized adhesive peptide poly-L-lysine and suggested that, in some way, fibronectin may be important during the formation of the actin- and myosin-containing contractile ring which is essential to cytokinesis. The existence of various transmembrane and cytoplasmic linking molecules between the extracellular matrix and the actin-containing microfilaments within the focal contacts between the membranes of cultured cells and the supporting surface has been established (Burridge, 1986). In support of such a role is the observation that Sertoli cells, which assumed a rather flattened, squamous appearance when cultured on plastic, retained a considerably more polarized morphology when plated on reconstituted basement membrane gels (Hadley et al., 1985).

In summary, while granulosa cells do secrete fibronectin, this property appears to be associated primarily with early rather than late stages of follicular development. These studies, utilizing both in-vitro and in-vivo methods of stimulating granulosa cell differentiation, have shown the existence of an inverse relationship between the secretion of this adhesive glycoprotein and follicular development toward progestagen production. While the precise influence of this extracellular matrix component on granulosa cell function in vivo remains to be determined, its high rate of production by granulosa cells early in follicular development may reflect participation by these cells in the synthesis of the basement membrane defining the granulosa and theca cell compartments.

I thank the NIAMDD for the purified preparation of FSH; Dr D. T. Armstrong (University of Western Ontario, London, Ontario, Canada) for the progesterone antiserum; Mr Oliver Cabaca and $\mathrm{Mr}$ Benoit Goyette for technical assistance; Mr D. Moher for assistance with the statistical evaluations; and Mrs E. Chan for help with the preparation of the manuscript. These studies were supported by a grant from the Medical Research Council of Canada (MA-10046). 


\section{References}

Amsterdam, A., Koch, Y., Lieberman, M.E. \& Lindner, H.R. (1975) Distribution of binding sites for human chorionic gonadotropin in the preovulatory follicle of the rat. J. Cell Biol. 67, 894-900.

Bagavandoss, P., Midgley, A.R. Jr \& Wicha, M. (1983) Developmental changes in the ovarian follicular basal lamina detected by immunofluorescence and electron microscopy. J. Histochem. Cytochem. 31, $633-640$.

Bortolussi, M., Marini, G. \& Dal Lago, A. (1977) Autoradiographic study of the distribution of $\mathrm{LH}$ (HCG) receptors in the ovary of untreated and gonadotrophin-primed immature rats. Cell Tiss. Res. 183, $329-342$

Burridge, K. (1986) Substrate adhesions in normal and transformed fibroblasts: organization and regulation of cytoskeletal, membrane and extracellular matrix components at focal contacts. Cancer Rev. 4, 18-78.

Carnegie, J.A. \& Tsang, B.K. (1984) The calciumcalmodulin system: participation in the regulation of steroidogenesis at different stages of granulosa cell differentiation. Biol. Reprod. 30, 515-522.

Carnegie, J.A., Dardick, I. \& Tsang, B.K. (1987) Microtubules and the gonadotropic regulation of granulosa cell steroidogenesis. Endocrinology 120, 819-828.

Carnegie, J.A., Byard, R., Dardick, I. \& Tsang, B.K. (1988) Culture of granulosa cells in collagen gels: the influence of cell shape on steroidogenesis. Biol. Reprod. 38, 881-890.

Dardick, 1., Caldwell, D.R., McCaughey, W.T.E. \& AlJabi, M. (1984) Nuclear morphologic and morphometric analyses of large noncleaved cell and immunoblastic non-Hodgkin's lymphomas. Human Pathology 15, 965-972.

Dorrington, J.H. \& Skinner, M.K. (1986) Cytodifferentiation of granulosa cells induced by gonadotropinreleasing hormone promotes fibronectin secretion. Endocrinology 118, 2065-2071.

Farookhi, R. (1982) Granulosa cell fusion allows heterologous receptor stimulation of adenylate cyclase and progesterone accumulation. Endocrinology 110, 1061-1063.

Fortune, J.E. \& Armstrong, D.T. (1977) Androgen production by theca and granulosa isolated from pro. estrous rat follicles. Endocrinology 100, 1341-1347.

Furman, A., Rotmensch, S., Kohen, F., Mashiach, S. \& Amsterdam, A. (1986) Regulation of rat granulosa cell differentiation by extracellular matrix produced by bovine corneal endothelial cells. Endocrinology 118, 1878-1885.

Gore-Langton, R.E., Lacroix, M. \& Dorrington, J.H. (1981) Differential effects of luteinizing hormonereleasing hormone on follicle-stimulating hormonedependent responses in rat granulosa cells and Sertoli cells in vitro. Endocrinology 108, 812-819.

Hadley, M.A., Byers, S.W., Suarez-Quian, C.A., Kleinman, H.K. \& Dym, M. (1985) Extracellular matrix regulates Sertoli cell differentiation, testicular cord formation, and germ cell development in vitro. J. Cell Biol. 101, 1511-1522.

Hsueh, A.J.W. \& Erickson, G.F. (1979) Extrapituitary action of GnRH: direct inhibition on ovarian steroidogenesis. Science, NY 204, 854-855.
Hynes, R.O. (1981) Fibronectin and its relation to cellular structure and behaviour. In Cell Biology of Extracellular Matrix, pp. 295-334. Ed. E. D. Hay. Plenum Press, New York.

Hynes, R.O. \& Yamada, K.M. (1982) Fibronectins: multifunctional molecular glycoproteins. J. Cell Biol. 95, 369-377.

Johnson, D.C. \& Nogueira-Araujo, G.M. (1981) A simple method of reducing the fading of immunofluorescence during microscopy. J. Immunol. Meth. 43, 349-350.

Leung, P.C.K. \& Armstrong, D. (1979) Estrogen treatment of immature rats inhibits ovarian androgen production in vitro. Endocrinology 104, $1411-1417$.

May, J.V. \& Schomberg, D.W. (1981) Granulosa cell differentiation in vitro: effect of insulin on growth and functional integrity. Biol. Reprod. 25, 421-431.

Morley, P., Armstrong, D.T. \& Gore-Langton, R.E. (1987) Fibronectin stimulates growth but not folliclestimulating hormone-dependent differentiation of rat granulosa cells in vitro. J. Cell Physiol. 132, 226-236.

Motta, P.M. \& Van Blerkom, J. (1979) Structure and ultrastructure of ovarian follicles. In Human Ovulation, pp. 17-38. Ed. E. S. E. Hafez. Elsevier/North-Holland Biomedical Press, Amsterdam.

Orczyk, G.P., Hichens, M., Arth, G. \& Behrman, H.R. (1979) Progesterone and 20a-dihydroprogesterone. In Methods of Hormone Radioimmunoassays, pp. 701-713. Eds B. M. Jaffe \& H. R. Behrman. Academic Press, New York.

Orly, J. \& Sato, G. (1979) Fibronectin mediates cytokinesis and growth of rat follicular cells in serum-free medium. Cell 17, 295-305.

Prabhu, V.K.K. \& Weisz, J. (1970) Effect of blocking ovulation in the rat by pentobarbital on ovarian $3 \beta$ hydroxysteroid dehydrogenase: a histochemical study. Endocrinology 87, 481-485.

Ruoslahti, E., Engvall, E. \& Hayman, E.G. (1981) Fibronectin: current concepts of its structure and functions. Collagen Res. 1, 95-128.

Savion, N. \& Gospodarowicz, D. (1980) Patterns of cellular peptide synthesis by cultured bovine granulosa cells. Endocrinology 107, 1798-1807.

Shalgi, R., Kraicer, P., Rimon, A., Pinto, M. \& Soferman, N. (1973) Proteins of human follicular fluid: the blood-follicle barrier. Fert. Steril. 24, 429-434.

Schrek, R. (1972) Ultrastructure of blood lymphocytes from chronic lymphocytic and lymphosarcoma cell leukemia. J. natn. Cancer Inst. 48, 51-64.

Skinner, M.K. \& Dorrington, J.H. (1984) Control of fibronectin synthesis by rat granulosa cells in culture. Endocrinology 115, 2029-2031.

Skinner, M.K., McKeracher, H.L. \& Dorrington, J.H. (1985) Fibronectin as a marker of granulosa cell cytodifferentiation. Endocrinology 117, 886-892.

Turksen, K., Aubin, J.E., Sodek, J. \& Kalnins, V.I. (1984) Changes in the distribution of laminin, fibronectin, type IV collagen and heparan sulfate proteoglycan during colony formation by chick retinal pigment epithelial cells in vitro. Collagen Rel. Res. 4, 413-426.

Yamada, K.M. (1981) Fibronectin and other structural proteins. In Cell Biology of Extracellular Matrix, pp. 95-114. Ed. E. D. Hay. Plenum Press, New York. 
Yamada, K.M. \& Olden, K. (1978) Fibronectins: adhesive glycoproteins of cell surface and blood. Nature, Lond. 275, 179-184.

Zoller, L.C. \& Weisz, J. (1978) Identification of cytochrome $\mathrm{P}-450$, and its distribution in the membrana granulosa of the preovulatory follicle, using quantitative cytochemistry. Endocrinology 103, 310-313.

Received 20 October 1989 